

\title{
THE INFLUENCE OF OUTSOURCING ON COMPANY TAXATION
}

\author{
COSTESCU, I[rina] D[aniela]; DUMITRESCU, C[onstantin] D[an] \& DURAN, V[asile]
}

\begin{abstract}
The issue of tax evidence is to determine who actually supports the tax burden, who is being affected by an increase of the tax volume. It was found, in the period after 1989, that if a tax is set to affect well defined taxpayers, then they often are able to pass their tax burden on others, even if the latter are not approved of the tax law. The fiscal/tax burden represents how much pressure is because of the taxes or, in other words, how heavy is the taxpayers' tax burden? So the taxpayers are trying to find solutions to reduce/decrease this burden. In this paper we intend to treat the decreasing of tax burden through the outsourcing of services and processes. This is possible after a short conceptual definition of both the notion of tax pressure and outsourcing
\end{abstract}

Keywords: outsourcing, fiscality, bureaucracy, manager ability

\section{INTRODUCTION}

In economics there are two great players, two great forces whose interests are often contrary/opposite but who can not function without each other. They are: the State represented by its various institutions and the economical agents.

The effects of the state tax applicable to the economical agents can be viewed from two perspectives.

1. In terms of the size of the tax degree

2. Under the terms of the degree of bureaucracy that is involved in the calculation, declaration and payment of taxes

\section{THE DEFINING ELEMENTS OF THE TAX BURDEN}

Tax rate measures the tax burden and can be calculated globally ( nationally), at company level (trader(economic agent) ) and at an individual level (tax payer - person). Every time this (taxe rate) appears as the percentage ratio, in which at numerator are the total compulsory levies requested the state (taxes, fees and other mandatory contributions) and at denominator the GDP, turnover (added value) or individual income, according to the level of the referred rate. Differences in the rate are depending on the structure of the compulsory levies.

Strict-sense tax burden is being calculated taking into account only the tax levy from the state budget (central budget and local budgests and social state security). But it does not reflect the total state levies and the entire socialized income. That's why the overall tax burden is being determined taking into account, beside taxes and fees payable to the central budget and local budgets, the so called social contributions, although they are managed through different budgets, but in the end they are all managed by the state, and these contributions are as binding as taxes. There are also countries where these contributions are being taxed, and social security and social protection are being financed from the state budget.

The tax burden, at national level, is determined by the funding needs of the public expenses. In addition to this pressure there is also a psychological tax pressure/burden (felt) that measures the tolerance limit of taxing. This appears in the form of individual tax burden established as the ratio between the total levies incurred by a taxpayer and his total pre-tax revenues. Of course it's level differs from the pressure at national level and is also different from one taxpayer to another because of the differential fiscal treatment and customized tax based on economic or social criteria.

So, the individual tax burden measures the sacrifice the taxpayer is forced to make by paying state taxes. It does not reflect the exact extent of the tax burden which must be assessed according to the degree of satisfaction of the subsistence needs and of the savings capacity of the after tax income. That's why it was mentioned that the proportional taxation is not as correct as the progressive one, because the tax is handled/supported different by someone who has an after tax income that does not meet the urgent living needs and thus it bears the same tax rate the one with a much higher income, who can live decently and can also save some.

The purchasing power of the net income remaining after the taxpayer's income and wealth direct taxation depends also on the level of the indirect taxes which are incurred from buying goods and services.

Therefore the real individual tax burden must be assessed in respect to all direct and indirect taxes that the taxpayer (person) pays, even if not all these are established by the law as being in its task.

The tax burden at the economic agent level is assessed as the percentage ratio between the mandatory payments required by the state (that needs to be paid) and the agent's added value, calculated for a specific time period, usually one year.

The level of the tax burden is under the influence of several factors specific to each country.

What should this level be, how it evolved over time, which is the situation today and which are the limits of the tax burden? Here are some questions for which the responses are not at all simple, because the problem, by it's nature, is really delicate, and opposite interests are being confronted. The state, on one hand, being faced 
with the continued growth of the public spending, whishes that the collected taxes grow. The taxpayers, on the other hand, are protesting against excessive taxation, and their most ardent whish is fiscal relaxation or even the total waiver of taxes. And if the state has not yet responded to this desire, and on the contrary continuously increased the fiscal pressure, the taxpayers are trying, by all means, to avoid the taxes.

Resolving such a conflict could be achieved by the existence of a reasonable tax pressure/burden (bearable), and according to the contemporary opinion of the economists by optimizing tax.

\section{THE CONCEPT AND THE SCOPE OF OUTSOURCING}

The discussions on outsourcing are varied, generating a surge of interest since the idea emerged that outsourcing is "new great revolution" [Corbett M.F. (2004)] or the most triumphant management system ("new management buzzword" [Power M.J., DeSouza K.C., Bonifazi C. (2006)]).

Outsourcing led managers around the world to wonder what it could do for them and how it could influence them. They are enthusiastic about the outsourcing's potential of helping them in managing and improving business.

In literature there are also some similar terms related/similar to outsourcing: shrinking, downsizing, spin-off, but they represent specific examples of applying the outsourcing methodology.

Observing the variety of situations in which outsourcing can also be found and following the theories related to this strategy, it can be said that when different authors discuss outsourcing, they normally do not discuss the same situation. Thus, it is necessary to define/delimit the types and categories of outsourcing in order to use them as efficiently as possible in management strategies.

Studying the views of several authors and considering different classification criteria, were identified the following outsourcing options [Mesnita]:

- long term/ medium term/short term

- resources/ administration/management

- general/transition/ process level

- on-shore/near-shore/off-shore

- one provider -one customer / one provider -more customers/more providers -one customer/more providers - more customers

- total/selective/partial

These options are presented in Figure 1. forms:

Broadly speaking, outsourcing can take the following

a) Outsourcing at company level by relocation and dividing the primary tasks: the transfer of services and activities can take place in the national subsidiaries of the company or in the overseas branches;

b) Outsourcing outside the company: in this case, the outsourcing of some services and activities may occur in companies in the same country or in foreign companies (also called offshore outsourcing).

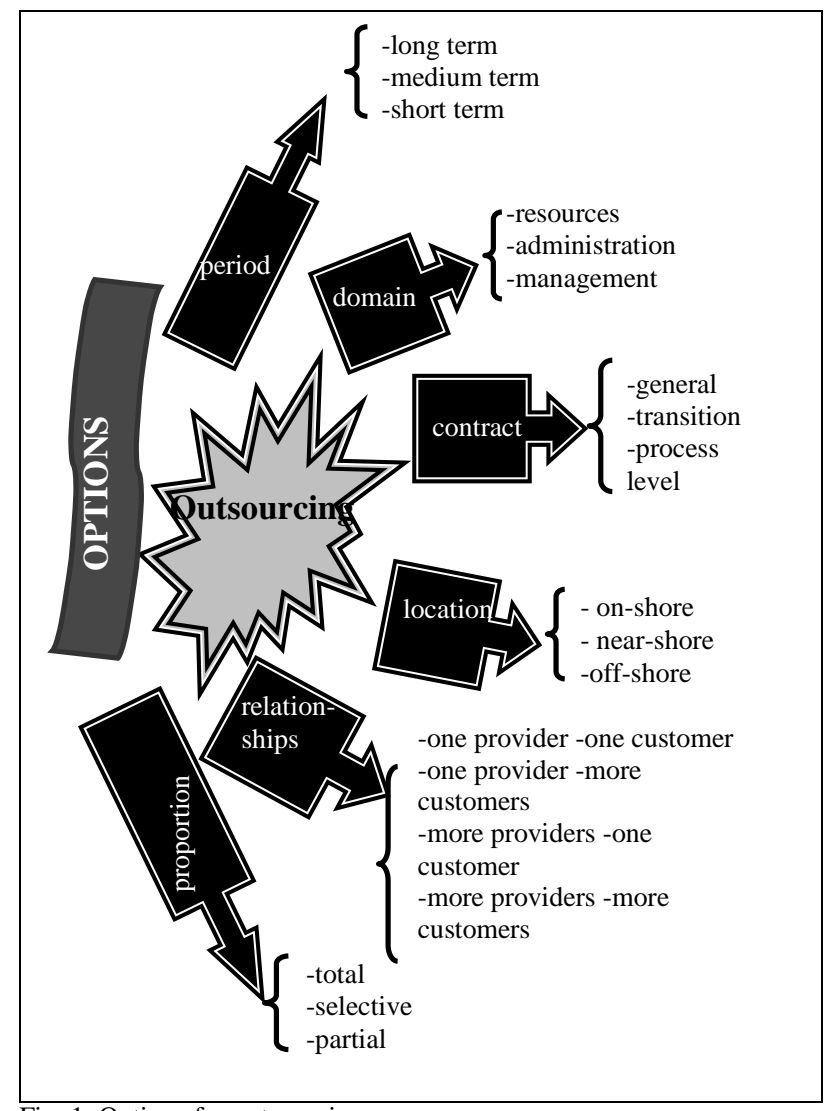

Fig. 1. Options for outsourcing

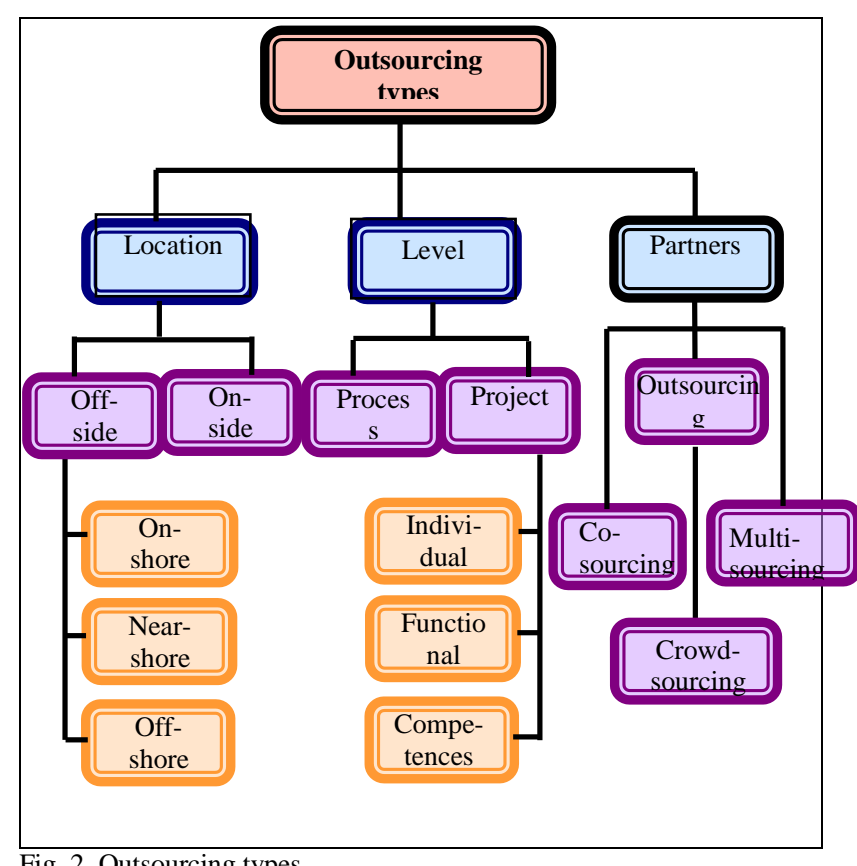

Fig. 2. Outsourcing types

So, there are a variety of categories and outsourced service models and processes, each with their own strengths, weaknesses and specific managerial concerns. Also, each type of outsourcing has its on management strategies. The main types of outsourcing are presented in Figure 2.

Outsourcing [Click R., Duening Th. (2005)] is based on the fundamental assumption that organizations should focus on their best achievable activity (have the best results at) and to transfer the remaining activities. A company should focus on its main activity (operating activity) and as little as possible on operating, for 
example, the adjacent departments. Theoretically, this concept is very logical, but in practice, it seems that it raises several challenges, which could cost more than the issues that are supposed to be resolved.

The theory of outsourcing is a complex concept and thus semantics, etymology and methodology captures the attention of many economists, engineers, politicians, sociologists from all over the world, of the media and even of ordinary/simple citizens. Their opinions, including the conceptual elements, do not overlap entirely. On the contrary, beyond the contact and interface areas, logical to understand, there are different viewpoints, ranging from the nuances of the same problems to contrast likely to cast shadows on the understanding of the phenomena and processes that give content to "outsourcing".

The word outsourcing comes from English, which consists of two words "out" and "sourcing". The latter represents the process of transferring an activity, responsibility or decision to a third party. By adding the word "out" to this notion, we can say that outsourcing represents the delegation of a task, responsibility and decisions to a third party (external company).

In conclusion, if sourcing is the act of transferring work from one entity to another, then outsourcing is the act of labor transfer to an outside party.

It is imperative to note that outsourcing is not a technology or a technological system but a business strategy.

When outsourcing does not work as planned, it is noticed that the companies/ businesses are largely dependent on a vendor and therefore very inflexible. Consequently, these challenges must be taken into account before a company decides to outsource.

\section{THE INCIDENCE OF FIRM TAXATION ON THE ECONOMICAL AND FINANCIAL RESULTS}

It is noticed, that in Romania, not even in the period before the global economic crisis, the tax burden was not low. But associating this problem with legislative instability, by the constant changes of rules, tax rates and reporting and collecting methodologies, the human resources management is laborious, involving heavy workload, and therefore a large number of staff.

It is true that at human resources level, the cost of salaries of those affected by the outsourcing process (which may be taken in by the outsourcing provider) decreases. But notable is the fact that together with this cost disappears the cost related to the staff evidence affected by outsourcing (preparation and filing of statements, bank fees related to salaries, IT engineer fee for reviewing the salary programs for each legislative change, etc..)

\subsection{The time evolution of the main fees, taxes and contributions}

A very important resource for the oparating of any trader (economical agent) is the human resource. Between employer and employee is a permanent conflict of interest, the employer wanting to have a lower labor expense and the employee wanting to have a salary as big as possible. But between employee and employer their interests should be able to align better in the interests of both parties, but here the state has always tried to intervene by increasing the contributions and through the lever called " minimum gross wage per economy."

A maximum of social contributions of employees related to the wage-earning fund in recent years, was reached in early 2001 when the employer paid:

- Contribution to social security $30 \%$

- Contribution to unemployment fund $5 \%$

- Health insurance contribution 7\%

- Contribution to the special fund of social solidarity with disabled persons $3 \%$

- Contribution to the special fund to support public education $2 \%$

- $\quad$ Total $47 \%$

By withholding from gross pay, employees are retained:

- Contribution to unemployment fund $1 \%$

- Contribution to additional pension 5\%

- Health insurance contribution 7\%

Starting with April 2001, came into effect the state social security law $19 / 2000$ by which the state social insurance contribution was divided unevenly between employees and employers, so the supplementary pension contribution of 5\% was removed from the employees' part and was replaced with the $11.67 \%$ employee social security contribution, and the employer's social security contribution become $23.33 \%$.

The employee withholding tax was in progressive compound rates of up to $40 \%$ until 2004 and since 2005 in an unique percentage tax of $16 \%$, calculated on the taxation basis. The taxation basis is equal to the gross wage minus the obligatory social contributions of the employee and minus a deduction between 0 and 650 lei, depending on the gross salary and on the number of dependents of the employee.

The withholding employee social contributions remained unchanged from 2003 until 2010, and they are:

- Contributions to state social insurance $9.5 \%$, currently $10.5 \%$

- Contribution to unemployment fund $1 \%$

- Contribution to Health Insurance 6.5\%

Starting with 01.01.2008 the unemployment fund contribution was reduced to $0.5 \%$

The evolution/progress of the social contributions paid by the employer is listed in the following table:

\begin{tabular}{|c|c|r|c|c|c|c|r|}
\hline YEAR & $\mathbf{1}^{*}$ & \multicolumn{1}{c|}{$\mathbf{2}^{*}$} & \multicolumn{1}{|c|}{$\mathbf{3}^{*}$} & $\mathbf{4}^{*}$ & $\mathbf{5}^{*}$ & $\mathbf{6}^{*}$ & $\mathbf{7}^{*}$ \\
\hline $\mathbf{2 0 0 3}$ & 24,50 & 0,50 & 3,50 & - & 7,00 & - & $\begin{array}{r}0,25 / \\
0,75\end{array}$ \\
\hline $\mathbf{2 0 0 4}$ & 22,00 & 0,50 & 3,00 & - & 7,00 & - & $\begin{array}{r}0,25 / \\
0,75\end{array}$ \\
\hline $\mathbf{2 0 0 5}$ & 22,00 & $\begin{array}{r}0,40- \\
3,60\end{array}$ & 3,00 & - & 7,00 & - & $\begin{array}{r}0,25 / \\
0,75\end{array}$ \\
\hline $\mathbf{2 0 0 6}$ & 19,75 & $\begin{array}{r}0,40- \\
3,60\end{array}$ & 2,50 & - & 7,00 & 0,75 & $\begin{array}{r}0,25 / \\
0,75\end{array}$ \\
\hline $\mathbf{2 0 0 7}$ & 19,50 & $\begin{array}{r}0,40- \\
3,60\end{array}$ & 2,00 & 0,25 & 6,00 & 0,85 & $\begin{array}{r}0,25 / \\
0,75\end{array}$ \\
\hline $\begin{array}{c}\text { ian.- } \\
\text { iun.2008 }\end{array}$ & 19,50 & $\begin{array}{r}0,40- \\
2,00\end{array}$ & 1,00 & 0,25 & 6,50 & 0,85 & $\begin{array}{r}0,25 / \\
0,75\end{array}$ \\
\hline $\begin{array}{c}\text { iul.- } \\
\text { nov.2008 }\end{array}$ & 19,50 & $\begin{array}{r}0,40- \\
2,00\end{array}$ & 1,00 & 0,25 & 5,50 & 0,85 & $\begin{array}{r}0,25 / \\
0,75\end{array}$ \\
\hline dec 2008 & 18,00 & $\begin{array}{r}0,40- \\
2,00\end{array}$ & 0,50 & 0,25 & 5,20 & 0,85 & $\begin{array}{r}0,25 / \\
0,75\end{array}$ \\
\hline
\end{tabular}




\begin{tabular}{|c|r|r|r|r|r|r|r|}
\hline $\mathbf{2 0 0 9}$ & 18,50 & $\begin{array}{r}0,15- \\
0,85\end{array}$ & 0,50 & 0,25 & 5,20 & 0,85 & $\begin{array}{r}0,25 / \\
0,75\end{array}$ \\
\hline $\mathbf{2 0 1 0}$ & 20,80 & $\begin{array}{r}0,15- \\
0,85\end{array}$ & 0,50 & 0,25 & 5,20 & 0,85 & $\begin{array}{r}0,25 / \\
0,75\end{array}$ \\
\hline $\mathbf{2 0 1 1}$ & 20,80 & $\begin{array}{r}0,15- \\
0,85\end{array}$ & 0,50 & 0,25 & 5,20 & 0,85 & - \\
\hline
\end{tabular}

Tab. 1. Contributions' evolution

* Note:

1. Contribution to state social insurance

2. Contribution to the fund of work accidents and occupational diseases

3. Contribution to unemployment fund

4. Contribution to the guarantee fund for the payment of wage claims

5. Contribution to health insurance

6. Contribution for leaves and allowances

7. Commission for the Labor Inspectorate

In the case of contributions to the work accidents and occupational diseases the percentage varies according to the CAEN class of the predominant activity of the economical agent. The ITM commission is paid differently in case the labour cards(carte munca) were kept and filled in by the economical agent or by the inspectorate.

Noteworthy is the year 2008, when the economical agents faced three legislative changes in the percentage shares of the payroll contributions.

Another important tax is the income tax. And this tax rate, as discussed earlier, decreased a lot from $38 \%$ to $25 \%$ and then to $16 \%$. The current budgetary policy is a liberal policy that operates on lower taxes, fewer, but with a larger tax base without too many exemptions, deductions, rebates, deferrals and with a better collection.

Before 2000 the income tax was 38\% and dividend tax was $1 \%$, Total $39 \%$ while the social contributions were well beyond the rate of $40 \%$. Since 2001 the income tax becomes $25 \%$ and the dividend tax increases to $5 \%$, then to $10 \%$ and from 2005 the tax income decreased to $16 \%$ and the dividends tax increased to $16 \%$. Also, the social contributions continuously decreased, with the exception of year 2005 when the unique tax rate of $16 \%$ was introduced, which was applied to both income and profit tax, an influence factor having been/was the fund for work accidents and occupational diseases which has variable rates, according to the NACE class of the predominant activity of the economical agent. (NACE $=$ National Classification of Economic Activities)

\section{CONCLUSION}

Depending on the influence of the tax size on businesses' financial and economic results, they found all sorts of solutions to avoid paying of part of these taxes.

Unfortunately not many managers make use of the outsourcing strategy, which, at least at cost level has only advantages. Because they don't know this strategy and because it is harder to bear contributions, businesses/economical agents have found the following solutions:

1. They employ staff based on civil service agreement. For this staff, initially the company did not pay any social contributions, retained only withholding tax. In
1998 with the entry of Law $145 / 1997$ of health insurance, for the civil convention staff the employer was obliged to pay contributions to social health insurance and civil convention employees were also retained social insurance contribution by withholding, in/by the virtue of/that social health insurance law was defined as an act of social solidarity that everyone has to contribute according to their income and to receive only when needed. Through the Government Emergency Ordinance 102/1999 was established the special fund of social solidarity with the disabled of $3 \%$ and through the Government Ordinance $75 / 1999$ the special fund to support public education of $2 \%$, percentages that are applied even to the civil service employees and through Law 19/2000 with effect from 1 April 2001, the social security forced to calculate state social insurance contribution, the civil service employees who did not have another job (with labour work), and then Law 53/2003 Labor Code took out these civil service conventions outside the law.

2. They paid a portion of employee money in untaxed money. Employees were working with the gross minimum economical wage but in reality they received a higher amount.

The bad side of things was that these untaxed money came from dividends thus leading to consumption rather than reinvestment of profit which led to a strong economic disinvestment. Basically there were many periods when the sum of the tax and dividend income was less than the social contributions that the ecoomical agent had to pay.

\section{REFERENCES}

[1] Herbei Marius, Popovici Dumitru, Finanțe Publice, Editura Mirton, Timişoara 2005

[2] Corbett M. F. (2004) The Outsourcing Revolution - Why It Makes Sense and How To Do It Right, Ed. Dearborn Trade, Chicago

[3] Power M. J., Desouza K. C., Bonifazi Carlo (2006) The Outsourcing Handbook - How to Implement a Successful Outsourcing Process, Kogan Page Limited, Londra , p. 2

[4] Click R., Duening Th. (2005) Business Process Outsourcing The Competitive Advantage, Ed. John Wiley \& Sons, New Jersey, p. 23

[5] Meşniţă G. - bibliografie teză 